\title{
Evaluation of psoriasis treatment with esomeprazole - a pilot study
}

\author{
Mauro BAFUTTO ${ }^{1}$, Enio Chaves OLIVEIRA ${ }^{2}$ and Schlioma ZATERKA ${ }^{3}$
}

Received 3/2/2019

Accepted 16/7/2019

ABSTRACT - Background - Psoriasis is an inflammatory skin disease that affects $1 \%-3 \%$ of Caucasian populations and may be persistent, disfiguring and stigmatising. Proton pump inhibitors (PPI) are potent blockers of gastric acid secretion. They are widely regarded as the agents of choice for the treatment of acid-peptic disorders. In addition to anti-secretory effects PPI have been found to have anti-oxidant properties and direct effects on neutrophils, monocytes, endothelial, and epithelial cells that might prevent inflammation. Objective - This study evaluated the treatment of psoriasis with esomeprazole. Methods - Ten patients were selected and psoriasis was evaluated according to Psoriasis Area and Severity Index (PASI). Exclusion criteria included concomitant use of any treatment for Psoriasis, organic diseases, use of other PPI than esomeprazole. Patients were medicated with esomeprazole $40 \mathrm{mg}$ B.I.D. for 90 days. At the 90 th day the patients were evaluated according PASI score. Results - Statistically significant results were seen when compared PASI before and at 90 th day of treatment $(P=0.0002)$. Conclusion - The use of esomeprazole for psoriasis resulted in excellent clinical results with a significant reduction of PASI score.

HEADINGS - Psoriasis. Esomeprazole. Proton pump inhibitors.

\section{INTRODUCTION}

Psoriasis is a chronic inflammatory disease that affects approximately $3 \%$ of the world's population, genetic based and immunomediated $^{(1)}$. It is a systemic disease characterized by skin lesions such as scaly patches, papules, and plaques, which usually itch, in areas of constant trauma to the skin such as elbows, knees, pretibial, scalp and sacral region ${ }^{(2)}$.

Plaques presence combined with psychogenic distress can reduce the quality of life ${ }^{(3)}$. Psoriasis is a stigmatizing dermatosis, in which patients suffer from discrimination, self-esteem issues, social isolation and rejection ${ }^{(4)}$.

This dermatosis is associated with genetic predisposition, but the transmission does not follow Mendelian standard. The Inheritance mode is multifactorial ${ }^{(5)}$ and environmental, geographic and ethnic aspects can interfere in its incidence ${ }^{(2)}$. Psychological, physical and surgical stress are well known triggering aggravating factor ${ }^{(6)}$.

Psoriasis is a chronic inflammation progressing to plaques formation and other skin lesions mainly mediated by TH1 and TH17 cells and lymphokines that are responsible for changing the keratinocytes, vascular network and own lymphocytes. Adhesion molecules expression in endothelial cells favors lymphocytes diapedesis with consequent greater recruitment of these cells. On the other hand there is the clonal proliferation and activation of lymphocytes and increased proliferation and delayed maturation of keratinocytes ${ }^{(7)}$.

Disease severity determines the therapeutic approach ${ }^{(8,9)}$. The most accepted treatments for psoriasis have been developed empirically or discovered by chance ${ }^{(1,10,11)}$. In patients with moderate to severe psoriasis, phototherapy or systemic immunomodulator medications, or both should be considered ${ }^{(1)}$.

Proton pump inhibitors (PPI) are used in the treatment of peptic disease because so far are the most potent known inhibitor of acid secretion of the stomach. In addition to this effect, they also have anti-inflammatory and antioxidant properties. Due to personal observations of improvement of psoriasis in patients with gastroesophageal reflux disease treated with PPI we decided to evaluate the use of esomeprazole magnesium in a series of cases with psoriasis.

\section{METHODS}

This study was approved by the Research Ethical Committee of Hospital Geral de Goiânia (CEPHGG: 756/14), and was done according to Helsinki Declaration. All patients gave their consent to participate.

Adult patients (18 years or older) with psoriasis were selected. Exclusion criteria included concomitant use of any treatment for psoriasis, organic diseases, use of other PPI than esomeprazole. 10 patients ( 6 male and 4 female, mean age $=47$ year $)$ were selected and psoriasis was evaluated by Psoriasis Area and Severity Index (PASI) (FIGURE 1). Patients were medicated with esomeprazole $40 \mathrm{mg}$ B.I.D. for 90 days. At the 90th day patients were again evaluated by PASI. Paired t test was used for statistical analysis.

Declared conflict of interest of all authors: none

Disclosure of funding: no funding received

${ }_{1}^{1}$ Universidade Federal de Goiás, Faculdade de Medicina, Disciplina de Gastroenterologia, Instituto Goiano de Gastroenterologia, Goiânia, GO, Brasil. ${ }^{2}$ Universidade Federal de Goiás, Faculdade de Medicina, Departamento de Cirurgia, Goiânia, GO, Brasil. ${ }^{3}$ Universidade de Campinas (UNICAMP), Faculdade de Medicina, Disciplina de Gastroenterologia, Campinas, SP, Brasil.

Corresponding author: Mauro Bafutto. E-mail: maurobafutto@yahoo.com.br 


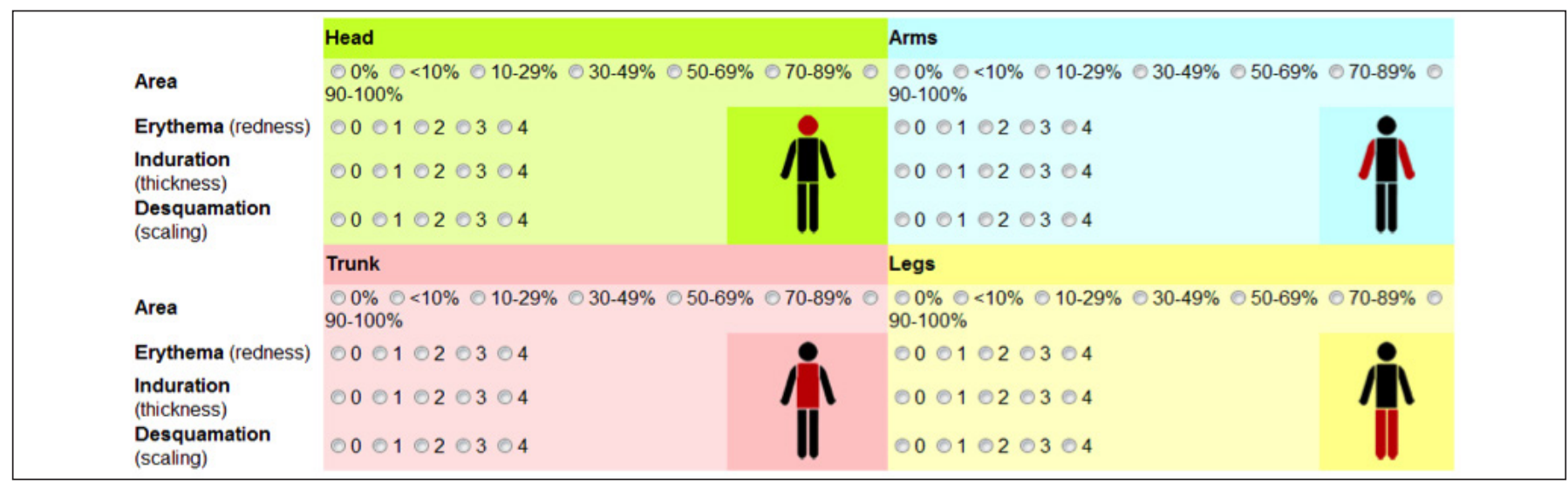

FIGURE 1. The PASI index calculation: It combines the severity (Erithema, Induration and Desquamation) and percentage of affected area.

\section{RESULTS}

Clinical data are summarized in TABLE 1 . Statistically significant results were seen when PASI before and at 90th day of treatment were compared: (mean \pm SD X mean \pm SD) $(5.52 \pm 2.93$ $\mathrm{X} 0.89 \pm 0.74) ; P=0.0002$. (FIGURE 2) At 90 th day of treatment most of the patients did not show erythema, induration or scaling of plaques. Fall in the PASI scale was $>75 \%$ (FIGURE 3 ).

TABLE 1. Clinical data and Psoriasis Area and Severity Index (PASI).

\begin{tabular}{|c|c|c|c|c|}
\hline \multirow{2}{*}{ Patients } & \multirow{2}{*}{ Sex } & \multirow{2}{*}{$\begin{array}{c}\text { Age } \\
\text { (years) }\end{array}$} & \multicolumn{2}{|c|}{ PASI } \\
\hline & & & Pre treatment & Post treatment \\
\hline 1 & M & 63 & 9.9 & 0.2 \\
\hline 2 & $\mathrm{~F}$ & 28 & 2.8 & 0.2 \\
\hline 3 & M & 60 & 8.1 & 0.4 \\
\hline 4 & $\mathrm{~F}$ & 68 & 2.6 & 0.4 \\
\hline 5 & $\mathrm{~F}$ & 52 & 3.6 & 1.8 \\
\hline 6 & M & 64 & 9.2 & 1.0 \\
\hline 7 & M & 39 & 3.4 & 1.4 \\
\hline 8 & $\mathrm{~F}$ & 44 & 2.7 & 1.4 \\
\hline 9 & $\mathrm{~F}$ & 61 & 6.3 & 1.1 \\
\hline 10 & M & 42 & 6.6 & 1.0 \\
\hline
\end{tabular}

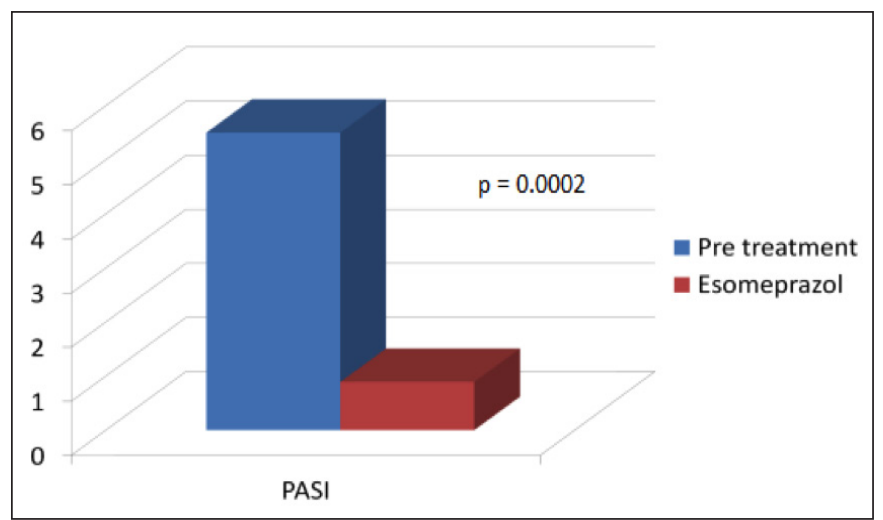

FIGURE 2. Pre treatment and a 90th day treatment PASI with esomeprazol $40 \mathrm{mg}$ B.I.D.

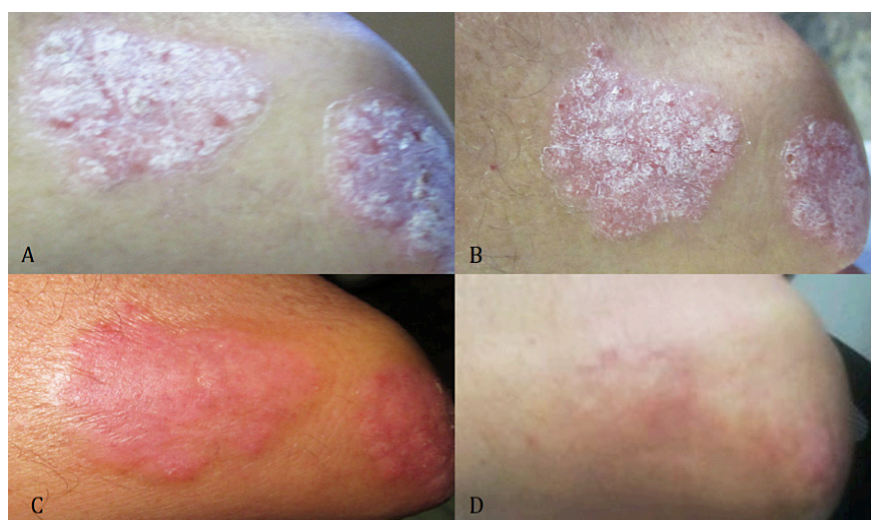

FIGURE 3. Patient treated with esomeprazol $40 \mathrm{mg}$ B.I.D.. A) Pre treatment. B) After 30 days. C) After 60 days. D) After 90 days of treatment.

\section{DISCUSSION}

Patients with psoriasis may be treated with esomeprazole with good improvement of their affected skin appearance. To the best of our knowledge this is the first report addressing this relation between proton pump inhibitor and skin disease.

The causes of psoriasis are not fully understood. It is generally considered a genetic disease, thought to be triggered or influenced by environmental factors. It is not only a disease of the skin involving others organ systems $s^{(1,3,6,7,10)}$.

Inflammation mediators are produced in different organs and tissues of patients with psoriasis. In the pathogenesis of psoriasis TH1 and TH17 lymphocites are mainly involved in the inflammatory process that leads to formation of plaques, especially the cytokines Interleukin 2 (IL-2), Interferon gamma (INF- $\gamma$ ) and tumor necrosis factor alpha (TNF- $\alpha 1)$. These lymphokines are responsible for changing the keratinocytes, vascular network and own lymphocites themselves. Adhesion expression molecules of endothelial cells favor diapedesis of lymphocites resulting in a greater recruitment of these cells. On the other hand there is the clonal proliferation and activation of lymphocytes and increased proliferation and delayed maturation of keratinocytes ${ }^{(7)}$.

Proton pump inhibitors are potent inhibitors of gastric acid secretion. They are widely regarded as the agents of choice for the treatment of acid-peptic disorders. In addition to anti-secretory 
effects, however, PPI have been found to have anti-oxidant properties and direct effects on neutrophils, monocytes, endothelial, and epithelial cells that might prevent inflammation. Also PPI inhibit the expression of intercellular adhesion molecule-1 (ICAM-1) and vascular cell adhesion molecule-1 (VCAM-1) as well as endothelialdependent neutrophil adhesion ${ }^{(12)}$.

Although different treatments schedules can help to control psoriasis symptoms, there is not yet a known treatment that cures the disease. Treatment depends on the severity of the disease, ranging from topic steroids to phototherapy, metotrexate, acicretin, ciclosporin or biologics ${ }^{(1,8,9,11)}$.

In this pilot study including a small number of patients ${ }^{(10)}$, in all of them we observed a significant improvement of the skin lesions using an oral, safe and well known medication.

\section{CONCLUSION}

Esomeprazole showed to be an excellent option of treatment for patients with psoriasis. These preliminary results need further larger randomized controlled studies.

\section{Authors' contribution}

Bafutto M and Oliveira EC: data collection, survey execution, statistical analysis, writing of text. Zaterka S: statistical analysis, writing of text.

\section{Orcid}

Mauro Bafutto. Orcid: 0000-0001-5585-3957.

Enio Chaves Oliveira. Orcid: 0000-0002-3502-7532.

Schlioma Zaterka. Orcid: 0000-0002-2260-9146.

Bafutto M, Oliveira EC, Zaterka S. Avaliação do tratamento da psoríase com esomeprazol - estudo piloto. Arq Gastroenterol. 2019;56(3):261-3.

RESUMO - Contexto - A psoríase é uma doença inflamatória da pele que afeta 1\%-3\% das populações caucasianas e pode ser persistente, desfigurante e estigmatizante. Inibidores da bomba de prótons (IBP) são potentes bloqueadores da secreção de ácido no estômago. Eles são considerados como os agentes de escolha para o tratamento de doenças ácido-pépticas. No entanto, além dos efeitos anti-secretores, IBP apresentam propriedades anti-oxidantes e efeitos diretos sobre os neutrófilos, monócitos, células epiteliais e endoteliais que podem impedir a inflamação. Objetivo - Avaliar o tratamento da psoríase com esomeprazol. Métodos - Foram selecionados pacientes adultos (18 anos ou mais) com psoríase. Os critérios de exclusão foram o uso concomitante de qualquer tratamento para a psoríase, doenças orgânicas e uso de outro IBP. Foram selecionados 10 pacientes e a psoríase foi avaliada pelo índice de gravidade e área da psoríase (Psoriasis Area and Severity Index - PASI). Os pacientes foram medicados com esomeprazol 40 mg BID por 90 dias. No nonagésimo dia os pacientes foram novamente avaliados por meio do PASI. Resultados - Dados estatisticamente significativos foram vistos quando comparado PASI antes do tratamento e no nonagésimo dia de tratamento, $P=0,0002$. Conclusão - $\mathrm{O}$ uso do esomeprazol para psoríase apresentou excelentes resultados clínicos com redução importante do PASI. Este estudo piloto é a primeira publicação na literatura inglesa sobre o tratamento da psoríase com esomeprazol.

DESCRITORES - Psoríase. Esomeprazol. Inibidores da bomba de prótons.

\section{REFERENCES}

1. Schon MP, Boehncke WH. Psoriasis. N Engl J Med. 2005;352:1899-912.

2. Consenso Brasileiro de Psoríase e Guias de Tratamento. [Access 2014 Jun 9]. [Internet]. Available from: http://www.solapso.org/archivos/consbra.pdf.

3. Weiss SC, Kimball AB, Liewehr DJ, Blauvelt A, Turner ML, Emanuel EJ. Quantifying harmful effect of psoriasis on health-related quality of life. J Am Acad Dermatol. 2002;47:512-8

4. Ludwig MWB, Oliveira MS, Muller MC, Moraes JFD. Qualidade de vida e localização da lesão em pacientes dermatológicos. An Bras Dermatol. 2009;84:143-50.

5. Bérard F, Nicolas JF. Phisiopathologie du psoriasis. Ann Dermatol Venereol. 2003;130:837-42.

6. Heller MM, Lee ES, Koo JYM. Stress as an influencing factor in psoriasis. Skin Therapy Lett. 2011;16:1-4.
7. Davidovici BB, Sattar N, Jörg PC, Puig L, Emery P, Barker JN, et al. Psoriasis and systemic diseases: Potential mechanistic links between skin disease and co-morbit conditions. J Invest Dermatol. 2010;130:1785-96.

8. Granstein RD. New treatments for psoriasis. N Engl J Med. 2001;345:284-87.

9. Heydendael VMR, Spuls PI, Opmeer BC, Borgie CAJM, Reitsma JB, Goldschmidt WFM, et al. Methotrexate versus cyclosporine in moderate-to-severe chronic plaque psoriasis. N Engl J Med. 2003;349:658-65.

10. Mendonça CO, Burden AD. Current concepts in psoriasis and its treatment. Pharmacol Ther. 2003;99:133-47.

11. Nickoloff BJ, Nestle FO. Recent insights into the immunopathogenesis of psoriasis provide new therapeutic opportunities. J Clin Invest. 2004;113:1664-75.

12. Kedika RR, Souza RF, Spechler JS. Potencial anti-inflammatory effects of proton inhibitors: A review and discussion of the clinical implications. Dig Dis Sci. 2009;54:2312-17. 